\title{
Esitys ja sen jälki
}

Saara Hacklin

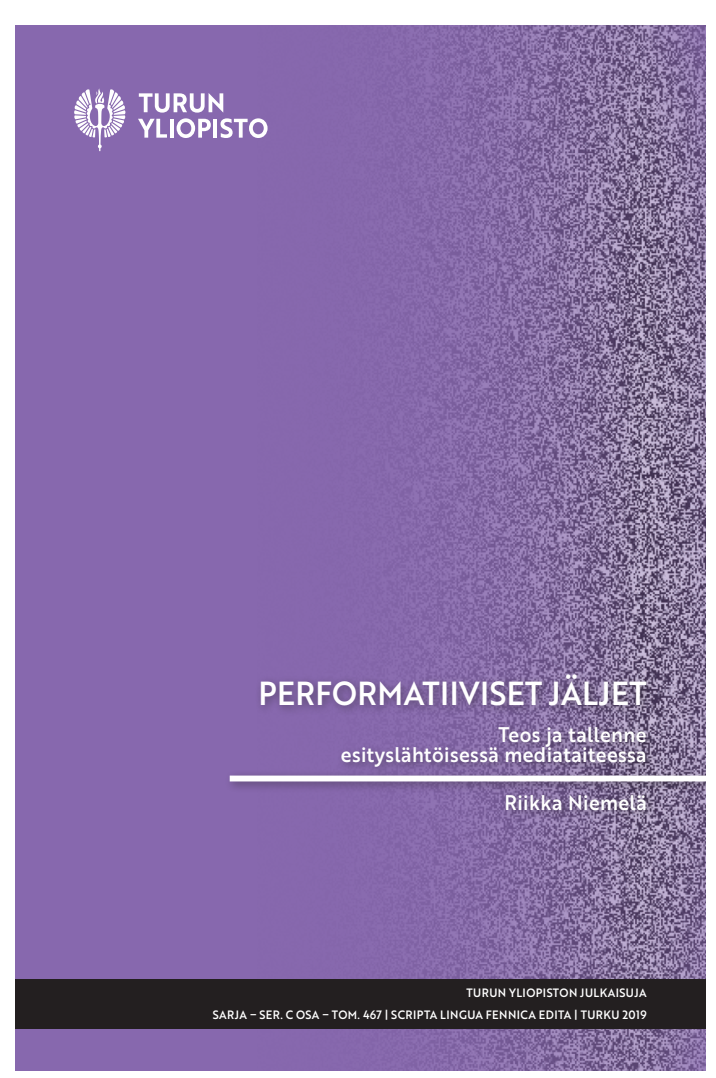

Riikka Niemelä, Performatiiviset jäljet. Teos ja tallenne esityslähtöisessä mediataiteessa (Turun yliopiston julkaisuja, 2019), 265 s. https://www.utupub.fi/hand$\underline{\text { le/10024/146971 }}$

Riikka Niemelän Turun yliopistossa viime vuonna tarkastettu väitöskirja tuo yhteen esitystaiteen ja mediataiteen risteäviä polkuja. Niemelän kunnianhimoinen työ kirjoittaa suomalaisen performanssitaiteen historiaa rajatusta näkökulmasta: sen kiinnostuksen kohteena on esityslähtöisen taiteen suhde teknisiin tallennuskeinoihin kuten televisioon, videoon ja internetiin. Teoksen aikajänne on varsin laaja. Siinä tarkastellaan paitsi Auki-ryhmää 1980-luvulta ja muutamia 2000-luvun taiteilijoita, kuten Eeva-Mari Haikalaa ja Minna Suoniemeä, myös vanhempia klassikoita kuten Mervi Buhl-Kytösalmi (aik. Deylitz-Kytösalmi) ja Jan-Erik Anderssonia.

\section{Tallenne, esitys ja katsoja}

Aivan aluksi on tietysti palattava performanssin ja tallenteen suhteeseen, sillä tämä kysymys on katoa- van taidemuodon kohdalla aina olennainen. Mikä on elävän esitystaiteen suhde dokumentaatioon? Voiko performanssi olla olemassa muualla kuin esityksessä? Vai onko sen ainoa olomuoto vain nykyhetkessä, kuten performanssitutkija Peggy Phelan aikoinaan väitti Unmarked teoksessaan (1993)? Phelanin määritelmä on sittemmin ollut kiistelyn kohteena ja se on osoittautunut kovin kapeaksi. Kuten Niemelä toteaa, esitystaidetta tehdään moninaisin keinoin ja esitystaiteeseen nivoutui jo varhaisessa vaiheessa kysymys erilaisista tallentamisen välineistä. Hän summaa, miten "2000-luvulla performanssiteoksen määritelmiä on ajateltu uudelleen myös tarkastelemalla miten sen 'elämä' jatkuu tallenteina" (21).

Niemelän teos osoittaa lukijalle kiehtovalla tavalla teknisen kehityksen ja esitystaiteen väliset kiemuraiset suhteet. Tutkimuksen esitykset ovat kaikki jollain lailla suhteessa teknisen tallentamisen välineisiin, ne kokeilevat uusia teknologioita rohkeasti - useissa tapauksissa hän osoittaa suomalaisten kokeilujen kytkökset kansainväliseen keskusteluun. Väitöstutkimuksen 
teosesimerkit haastavat kysymystä esityksen ja tallenteen, esiintyjän ja suoraan samassa tilassa läsnä olevan yleisön välisestä suhteesta. Rajanveto näiden kahden välillä ei ole ollenkaan selvää. Esitys jättää jäljen ja samalla jatkaa elämäänsä, muun muassa esiintyjän ja yleisön muistoissa, valokuvissa, esityskuvauksissa.

Taideteoksen ainutkertaisuus ja toisinnettavuus on ollut keskeinen kysymys 1900-luvulla. Walter Benjaminin "Taideteos mekaanisen uusinnettavuuden aikakaudella" -esseen (1935) esiin nostama kysymys on saanut taiteilijat haastamaan ajatusta alkuperäisestä ja ainutkertaisesta teoksesta. Monistaminen ja toisto ovat kiinnostaneet taiteilijoita erityisesti 1960-luvulta lähtien. Niemelä antaa kirjassaan kuvan siitä, miten sekä käsitys esitystaiteesta että keinot, joilla esityksiä on mahdollista tallentaa, ovat vuosikymmenten saatossa muuttuneet.

Niemelän tutkimuskohteena on pakeneva ja hajanainen esitys. Ehkä juuri siksi tutkimuksen teoreettinen viitekehys ammentaa fenomenologiasta. Hän kirjoittaa, miten tutkimuksen painopiste siirtyy alkuperäisestä esityksestä katsojaan: kiinnostuksen kohteena on, miten esitys ilmenee, miten esitys tulee kohdattavaksi. Fenomenologia on toki innoittanut suoraan esitystutkimusta, mutta Niemelän motivaatio kääntyä sen puoleen liittyy nimenomaan siihen, miten fenomenologia siirtää huomion havaitsemiseen. Ihminen havaitsee maailmaa oman ruumiinsa kautta - maailma ilmenee meille aina jostain näkökulmasta, antautuu kohdat- tavaksi jostain käsin. Fenomenologian avulla onkin mahdollista hahmottaa performanssiteos erilaisista ilmentymistä muodostuvaksi. Myös nauhoille, videoille tai internetiin luotu esitys on ruumiillisesti koettavissa, se on yhtä lailla fragmentaarinen ja jatkuvasti muuttuva. Niemelän tulkinnan mukaan fenomenologian näkökulmasta esityksen tallenne on osa esitystä. Niemelän kirjassa on fenomenologisen lähestymistavan lisäksi varsin laajasti edustettuina esitystaiteen ja mediataiteen tuoretta tutkimusta ja teoreettista keskustelua.

\section{Esityksiä kameralle}

Niemelän tapaustutkimukset haastavat kaikki jollain tavoin ajatusta esityksen ainutkertaisuudesta, alkuperäisestä ja eheästä teoksesta, joka olisi ollut jossain koettavissa ja sen jälkeen iäksi kadonnut. Jo pelkkä väitöskirjaan valittujen esitysten kirjo osoittaa Niemelän kohteen moninaisuuden: Auki II ryhmä, jonka ytimessä olivat Lea ja Pekka Kantonen, teki Vanhan galleriaan myöhemmin performanssiesityksen. Se hyödynsi valokuvia, tallennettuja esityksiä sekä live-esitystä. Haikalan ja Suoniemen työt taas ovat 2000-luvun ensimmäiseltä vuosikymmeneltä ja haastavat mediataiteen ja performanssitaiteen genrerajoja.

Ajallisesti ja eri medioiden näkökulmasta väitöskirjan tapaustutkimusten kirjo on vielä laajempi. Varhaisimmat esimerkit lähtevät liikkeelle 1960-luvulta ja kietoutuvat televisioon ja uuteen teknologiaan. 1970-luvulta Niemelä nostaa esiin Saksassa opiskel- leen Mervi Kytösalmi-Buhlin teoksia. Ajallisesti varhaisimmat esimerkit ovat 1960-luvulta. Niemelä nostaa esiin kiinnostavan kuriositeetin, 1960-luvun TV-happeningin. Kokeiluksi jääneistä poikkitaiteellisisista happeningeistä esimerkiksi nousee tanssitaiteilija Riitta Vainion kokeelliset esitykset muun muassa yhdessä Eino Ruutsalon kanssa. Toinen esimerkki varhaisista poikkitaiteellisista teoksista liittyy happeningeihin, joissa taide ja uusi teknologia kohtasivat live-tilanteessa: Eino Ruutsalon "Valo ja liike" -näyttelyn yhteydessä järjestetty "Sähkö-shokki-ilta" Amos Andersonin taidemuseolla vuonna 1968 yhdisti runoutta ja koneita. Vastaavasti Riitta Vainion ja Erkki Kurenniemen yhteistyössä tekemä Dimi-baletti (1971) yhdisti tanssia ja ääntä, kun Kurenniemen DIMI-O muunsi Vainion liikkeet ääniksi.

1960-luvun teknologiaoptimismista kirjassa siirrytään luontevasti internetin mahdollistamiin kokeiluihin 1990-luvun alkuun. Niemelä nostaa varhaisesta internetiä hyödyntävästä taiteesta esimerkiksi muun muassa Marikki Hakolan ja Jan-Erik Anderssonin. Jan-Erik Anderssonin Clean/Puhdas/Ren (1995) perustui taiteilijan Galleria Sculptorissa pitämään näyttelyyn. Taiteilija asui galleriassa esityksen ajan ja pyrki pitämään sitä puhtaana. Andersson tuotti joka päivä internetiin teosta, joka yhdisti taiteilijan ajatuksia, valokuvia ja tekstejä toisten kirjoittajien, kuten Erkki Pirtolan ja Jyrki Siukosen, ajatuksiin.

Niemelän kirja osoittaa lukijalle, miten esityksen 
suhde teknologiaan on kehittynyt. Internetin myötä tilanne muuttuu vain monimutkaisemmaksi, kun esitystaiteen piiriin voi lukeutua teoksia, jotka tapahtuvat esimerkiksi Facebookin uutisvirrassa tai vaikkapa Liikenneviraston kelikameroissa, kuten Tatu Gustafssonin teoksessa Weather Camera Self-Portraits (2012-).

Kiinnostavaa on myös miettiä rinnakkain kahden eri aikakauden videoperformansseja, esimerkiksi miten Mervi Buhl-Kytösalmen sekä seuraavan sukupolven tekijöiden Minna Suoniemen ja Eeva-Mari Haikalan teoksissa kaikissa on mielestäni vahva feministinen eetos, vaikkei feminismi tekijöille olekaan selviö. Mervi Buhl-Kytösalmi opiskeli Düsseldorfin taidekatemiassa, jossa Nam June Paikilla oli oma "Die Klasse Paik". Buhl-Kytösalmi kuvasi omaa kiinnostuksen kohdettaan: "Henkilö, liikunta, tila, aika” (205). Hänen teoksensa tutkivat ruumiillista maailmassaolemista. Buhl-Kytösalmi teki esityksiä, jotka kuvattiin videolle ja hänelle nämä esitykset olivat itsenäisiä taideteoksia. Samansuuntaista työskentelytapaa käytti parikymmentä vuotta myöhemmin Eeva-Mari Haikala, jonka Tableaux Vivants-sarja (2006) Super 8-nauhoille näyttää yhtä lailla tutkivan ruumiin suhdetta tilaan, ajallista kokemusta. Molempien taiteilijoiden eetoksessa on myös vahvaa eletyn ruumillisuuden tuntua, millaista on asettautuminen tilaan, miten ruumis hitaasti keskittyy johonkin liikesarjaan tai eleeseen - tämän keskittyneen, yksinkertaisen liikkeen myötä voi hakea elettyä yhteyttä katsojaan.

\section{Hauraan uuden äärellä}

Riikka Niemelän ansiokas väitöskirja muistuttaa nykytaiteen historiasta, sen kokeellista juurista ja kiinnostuksesta uuteen teknologiaan. Tutkijana Niemelä osoittaa lukijalle punaisen langan 1960-luvulta 2000-luvulle ja auttaa näkemään esitystaiteen moninaisuuden ja sen muuntautumiskyvyn. Esimerkit saavat myös ajattelemaan sitä, miten hänen valitsemansa teosmuotoa haastavat kokeilut ovat vaarassa jäädä tutkimuksen ulkopuolelle. Miten tutkia tapahtumamuotoista, vain hetkellisesti mahdollisesti verkossa olemassa olevaa? Entä kenen tehtävä on tätä tallentaa? Näenkin 2020-luvun taidemaailmassa Niemelälle paljon mahdollisuuksia jatkotutkimukselle. Yhä useampi nykytaiteilija liikkuu taidemuotojen välillä, esitystaiteen kentältä galleriaan ja takaisin, teknologiaa hyödyntäen. Entäpä millaisia näkökulmia Niemelä löytäisi esimerkiksi post-internet-taiteen saralta? Ajattelen esimerkiksi jo alan klassikoksi muodostunutta Amalia Ulmanin Instagram-esitystä Exellencies and Perfections (2018), jossa taiteilija kehitti itsestään Instagram-persoonan. Epäilemättä tulevaisuudessa näemme edelleen yhä uusia avauksia. Tätäkin kirjoitusta on tehty aikana, jolloin moni miettii esityksen ja teknologian suhdetta uudella tavalla, kiitos kevään 2020 koronaepidemian.
FT Saara Hacklin on Nykytaiteen museossa työskentelevä kuraattori.

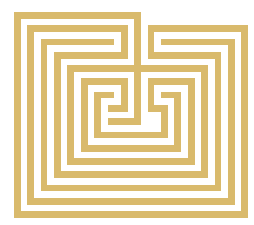

